\title{
BAZI TAHIL BENZERİ ÜRÜNLERİN GLUTENSİZ KEK ÜRETİMİNDE KULLANIMI
}

\author{
Ceren Mutlu ${ }^{1,2^{*}}$, Sultan Arslan Tontul ${ }^{3}$, Cihadiye Candal ${ }^{1,4}$, Mustafa Erbaş ${ }^{1}$ \\ ${ }^{1}$ Akdeniz Üniversitesi Mühendislik Fakültesi Gıda Mühendisliği Bölümü, Antalya, Türkiye \\ ${ }^{2}$ Balıkesir Üniversitesi Mühendislik Fakültesi Gıda Mühendisliği Bölümü, Balıkesir, Türkiye \\ ${ }^{3}$ Selçuk Üniversitesi Ziraat Fakültesi Gıda Mühendisliği Bölümü, Konya, Türkiye \\ ${ }^{4}$ Artvin Çoruh Üniversitesi Sağlık Bilimleri Fakültesi Beslenme ve Diyetetik Bölümü, Artvin, Türkiye
}

Geliş / Received: 20.03.2019; Kabul / Accepted: 28.07.2019; Online bask1 / Published online: 11.08.2019

Mutlu, C., Arslan Tontul, S., Candal, C., Erbaş, M. (2019). Bazı tahıl benzeri ürünlerin glutensiz kek üretiminde kullanımı. GID $A$ (2019) 44 (5): 770-780 doi: 10.15237/gida.GD19073

Mutlu, C., Arslan Tontul, S., Candal, C., Erbas, M. (2019). Baž tahıl benzeri ürünlerin glutensiz kek üretiminde kullanmi. GIDA (2019) 44 (5): 770-780 doi: 10.15237/gida.GD19073

\section{ÖZ}

Araştırmada bazı tahıl benzeri ürünlerin (çiya, amarant, kinoa ve karabuğday) glutensiz kek üretiminde kullanılabilirliğinin ve bu ürünlerin keklerin bazı özellikleri üzerine etkilerinin belirlenmesi amaçlanmıştır. Bu amaçla dört farklı kek unu karışımı; mısır (\%45) ve pirinç (\%45) nişastası ve tam tane olarak öğütülmüş tahıl benzeri ürünler (\%10) kullanılarak hazırlanmıştır. Bu karışımlar ile üretilen kek örnekleri ve kontrol kek örneklerine; bazı fiziksel (renk, spesifik hacim ve tekstür), kimyasal (nem, su aktivitesi, dirençli nişasta, glisemik indeks ve antioksidan aktivite) ve duyusal analizler yapılmıştır. Kek örneklerinin sertlik ve çiğnenebilirlik değerlerinin 1234.21-1709.50g ve 668.09-996.27 aralıklarında değiştiği belirlenmiştir. Tahıl benzeri ürün ilavesiyle hazırlanan keklerin dirençli nişasta içeriklerinin \%0.17-0.22 arasında olduğu ve tahmini glisemik indekslerinin ise 55 değerinden düşük olmaları sebebiyle düşük glisemik indeksli gida sınıfı içerisinde yer alabileceği tespit edilmiştir. Yapılan değerlendirmeler neticesinde glutensiz keklerin çeşitlendirilmesinde tahıl benzeri ürünlerin kullanılabileceği ve bunların arasında ise çiyanın yumuşaklık, yüksek antioksidan aktivite ve duyusal özellikleri itibariyle öne çıktı̆̆ sonucuna ulaşılmıştır.

Anahtar kelimeler: Çìa, amarant, kinoa, karabuğday, glutensiz kek, çölyak

\section{USAGE OF SOME PSEUDOCEREALS IN THE GLUTEN-FREE CAKE PRODUCTION}

\begin{abstract}
The aim of this study was to determine the usability of pseudocereals (chia, amaranth, quinoa, and buckwheat) in cake production and their effect on some properties of cake. For that purpose, four different cake flour mixtures were prepared by using corn and rice starches (45:45\%) and whole-grain milled pseudocereals (10\%). Some physical (color, specific volume, and texture), chemical (moisture, water activity, resistant starch, glycemic index, and antioxidant activity) and sensory analyses were performed to both samples produced with these mixtures and the control samples. The hardness and chewiness values of the samples varied between 1234.21-1709.50g and 668.09-996.27, respectively. The resistant starch content of the samples with pseudocereals was between $0.17-0.22 \%$ and they could be classified as low glycemic index food because their glycemic index values were lower than 55 . As a result, pseudocereals could be used to vary gluten-free cake and chia containing cake samples distinguished in terms of softness, high antioxidant activity and sensorial properties among other cake samples with pseudocereals.
\end{abstract}

Keywords: Chia, amaranth, quinoa, buckwheat, gluten-free cake, celiac

*Yazışmalardan sorumlu yazar/ Corresponding Author

$\triangle$ cerenmutlu@akdeniz.edu.tr, $\quad$ (+90) 2423104317

煦 $(+90) 2423106306$ 


\section{GİRİ̧}

Gluten; ekmek, kek, makarna ve erişte gibi tahıl ürünlerinin üretimi açısından önemli bir proteindir. Gliadin ve glutenin olmak üzere iki farkl fraksiyonun birleşiminden oluşmakta olup, buğdayın toplam protein içeriğinin yaklaşık $\% 80$ kadar1 glutendir (Rosell vd., 2014). Gluten proteini hamurun yapışmasını engellemekte ve mayalama işlemi sırasında oluşan gazların tutulmasını sağlayarak; ürünün hacmini, elastikiyetini ve kabuk yapısını etkilemektedir (Delcour vd., 2012).

Tahıl ürünlerinin teknolojik özellikleri üzerine birçok olumlu etkiye sahip olan gluten, alerijler ve intoleranslarla ilgili olarak insan sağlığı üzerinde bazı olumsuz etkilere de sahiptir. Gluten tüketimi ile gida alerjisi, çölyak hastallğı ve gluten hassasiyeti olmak üzere üç farklı patolojik durum meydana gelebilmektedir (Rosell vd., 2014). Glutene bağlı gida alerjisi, toplumun yaklaşık $\% 0.2-0.5$ kadarını etkileyen ve önemli klinik etkileri olan bir hastalıktır (Zuidmeer vd., 2008). Çölyak hastalığı otoimmün bir rahatsızlıktır ve toplumun yaklaşık \%0.1-1.6 kadarının bu rahatsızlı̆ga sahip olduğu bildirilmiştir. $\mathrm{Bu}$ hastalığa sahip kişiler tarafindan buğday, çavdar, arpa ve bazı yulaf çeşitleri tüketildiğinde çeşitli sağlık sorunları ortaya çıkabilmektedir (Abadie vd., 2011). Gluten hassasiyeti ise buğday alerjisi ve çölyaktan faklı olan ve son yllarda keşfedilen patolojik bir durumdur. Bu hastalıkla ilgili olan gida bileşenleri ve metabolizmadaki mekanizma tam olarak aydınlatılamamış olmakla birlikte, gluten proteininin yanı sira ekmekte bulunan diğer bileşenlerin de bu tür bir hassasiyet üzerinde etkili olduğu bildirilmiştir (Rosell vd., 2014; Bernardo ve Peña, 2012).

Günümüze kadar belirtilen gluten kaynaklı alerji ve intoleransları taşıyan bireylerde bu etkilerin önlenmesi ve/veya azaltılmasinda en etkili tedavi yöntemi, gluten içermeyen güvenli ve besleyici olarak dengeli gidalar tüketilmesidir (Bernardo ve Peña, 2012). Bu amaçla un ve unlu mamuller, soslar, pizzalar, şeker şurupları ve şekerlemeler olmak üzere birçok glutensiz gida geliştirilmiştir (Arendt ve Dal Bello, 2011; Gutiérrez, 2018; Linares-García vd., 2019). Glutensiz gidaların zenginleştirilmesi ve gluten proteininin sağladığ1 teknolojik özelliklerin bu ürünlerde de sağlanabilmesi için ise bu ürünlere baklagiller ve baklagil unlanı (mercimek, bakla, bezelye, nohut vb.), süt ve süt ürünleri, tahıl benzeri ürünler (çiya, amarant, kinoa, karabuğday vb.), besinsel lifler ve hidrokolloidler (agar, aljinat, gamlar vb.) gibi bileşenler ilave edilmiştir (Arendt ve Dal Bello, 2011; Pellegrini ve Agostoni, 2015).

Doğal olarak gluten içermeyen ve bu nedenle gluteni içeren tahıllara sağlıklı alternatifler olarak glutensiz diyette kullanılabilen çiya, amarant, kinoa ve karabuğday gibi tahıl benzeri ürünler, glutene bağlı alerji ve intoleransları olan bireyler ve bunun dışındaki bireysel tüketim tercihleri sebebiyle diğer tüketiciler tarafindan son yillarda büyük ilgi görmektedir. Bu ilgi tahıl benzeri ürünlerin sahip olduklar1 zengin besin bileşimlerinden kaynaklanmaktadır. Tahıl benzeri ürünler nişasta içerikleri nedeniyle önemli enerji kaynakları olmalarının yanı sıra; kaliteli protein, besinsel lif ve doymamış yağ asitleri bakımından zengin lipitleri de içermektedirler. Ayrıca tahıl benzeri ürünlerin yapılarında vitamin, mineral, esansiyel yağ asitleri, fitosteroller ve polifenoller gibi diğer biyoaktif bileşenler de bulunmaktadır (Alvarez-Jubete vd., 2010).

$\mathrm{Bu}$ araştırmada; çiya, amarant, kinoa ve karabuğday ilavesi ile besinsel açıdan zenginleştirilmiş glutensiz karışımlardan üretilen kek örneklerinin bazı fiziksel, kimyasal ve duyusal niteliklerinin, gluten içeren normal unla ve gluten içermeyen ticari karışım ile hazırlanan kek örneklerinin ilgili özellikleriyle karşılaştırılması amaçlanmıştır. Böylece bu araştırma ile normal un ile hazırlanan kek örneklerinin özelliklerine en yakın özellikleri taşıyan ve tahıl benzeri ürün ilavesi ile besinsel açıdan daha zengin olan glutensiz karışım belirlenmiş olacaktır.

\section{MATERYAL VE METOT}

\section{Materyal}

Kek örneklerinin üretimi için kullanılan malzemeler (un, yumurta, ayçiçek yağı, şeker, kabartma tozu ve vanilya) ve tahil benzeri ürünler (çiya, amarant, kinoa ve karabuğday) piyasada iyi bilinen firmalardan ambalajlı ticari ürünler olarak 
satın alınıp kullanılmıştır. Araştırmada kullanılan kimyasal maddeler ise analitik saflıkta temin edilerek kullanılmışır.

\section{Kek Üretim Metodu}

\section{Kek ununun hazırlanması}

Glutensiz kek üretimi için; eşit miktarda mısır $(\% 45)$ ve pirinç (\%45) nişastası karıştırılmış ve bu karışıma tam tane olarak yaklaşı un partikül boyutunda öğütülmüş (Bosch, MKM6000, Slovenya) olan çiya, amarant, kinoa veya karabuğday unları son karışımda \%10 olacak şekilde ayrı ayrı katkılanarak dört farklı un karışımı hazırlanmıştır. Normal un ve ticari glutensiz kek karışımı ise iki farklı kontrol örneği üretmek için kullanılmıştır. Böylelikle araştırma, altı farklı kek üretimi yapılarak gerçekleştirilmiştir.

\section{Kek karışımının hazırlanması}

Kek karışımının hazırlanmasında standardize kek formülasyonu kullanılmıştır. $\mathrm{Bu}$ amaçla eşit miktarda; kek unu karışımı (125 g), tam yumurta (125 g), yağ (125 g) ve şeker (125 g) plastik bir kaba tartılmış ve bir karıştırıcı yardımı ile karıştırılmıştır. Homejenize edilen kek karışımı içerisine toplam miktarın \%1.2'si oranında kabartma tozu (3 g) ve vanilya (3 g) ilave edilmiş ve bu karışım yeniden karıştırılmışıtır (Wilderjans vd., 2013). Hazırlanan kek karışımından yuvarlak kek kalıbının bölmelerine her bir kek örneği için $40 \mathrm{~g}$ tartılmıştır. Kalıba tartılan kek hamurları $225^{\circ} \mathrm{C}$ sıcaklıkta 30 dakika süre ile pişirilmiştir. Pişirme işleminden sonra kekler soğutularak kalıplar içerisinden çıkartılmışır. Kek örneklerine uygulanan fiziksel ve duyusal analizler üretimden 1 saat sonra $25^{\circ} \mathrm{C}$ sıcaklıkta gerçekleştirilmiştir. Kimyasal analizler ise ögütülen ve $-18^{\circ} \mathrm{C}$ de plastik polietilen poşetler içerisinde saklanan örneklerde set halinde gerçekleştirilmiştir.

\section{Analiz Metotları}

\section{Renk analizi}

Kek örneklerinin renk analizleri, renk ölçüm cihaz1 (Chroma Meter CR-400, Konica-Minolta Sensing Inc., Osaka, Japonya) kullanılarak tespit edilmiştir. Renk ölçüm sonuçları, Hunter $L^{*}[(0)$ siyah - (100) beyaz], $a^{*}[(+)$ kırmızı - (-) yeşil $]$ ve $b^{*}[(+)$ sarı $-(-)$ mavi] değerleri olarak belirlenmiştir.

\section{Spesifik hacim analizi}

Kek örneklerinin hacimleri kolza tohumu ile yer değiştirme prensibine göre belirlenmiş ve sonuçlar mL/g olarak verilmiştir (Román vd., 2017).

\section{Tekstür analizi}

Kek örneklerinin tekstür profil analizi, tekstür ölçüm cihazı (TA.TX plus, İngiltere) ile gerçekleştirilmiştir. Kek örnekleri bütün halde ve oda sıcaklığında analiz edilmiştir. Ölçüm sırasında SMSP/100 silindirik prop kullanılmıs ve analiz 5 kg'lık yük hücresi ile gerçekleştirilmiştir. Analizde test hiz1 $3 \mathrm{~mm} / \mathrm{s}$, gerilme oran1 \%30 ve gerilme kuvveti 3 g olarak ayarlanmıştır.

\section{Nem içeriği ve su aktivitesi analizi}

Kek örneklerinin nem içeriğinin belirlenmesi amacıyla, $2 \mathrm{~g}$ örnek tartılarak $105^{\circ} \mathrm{C}$ sıcaklığındaki etüv içerisine yerleştirilmiştir. Nem içeriği sonuçları ağırlık değişimi farkından hesaplanarak yüzde nem içeriği (\%) olarak verilmiştir.

Kek örneklerinin su aktivitesi $\left(a_{w}\right)$ değerleri, su aktivitesi tayin cihazı (Aqua Lab 4TE, Decagon Divices, USA) kullanılarak belirlenmiştir.

\section{Dirençli nişasta analizi}

Kek örneklerinin enzime dirençli nişasta (EDN) miktar1, standart metoda (AACC, 2011) göre dirençli nişasta enzim kiti (K-RSTAR, Megazyme Int. Wicklow, İrlanda) kullanılarak tespit edilmiştir. Bu amaçla öncelikle ögütülmüss kek örneklerinin n-hekzan ile yağı uzaklaştırılmıştır. Yağ1 uzaklaştırılmış örneklerden $100 \mathrm{mg}$ tartılmış ve üzerlerine pankreatik $\alpha$-amilaz (3 Ceralpha Unit/mg) ve seyreltilmiş amiloglukozidaz (300 $\mathrm{U} / \mathrm{mL}$ ) enzimlerini içeren çözeltiden $4 \mathrm{~mL}$ ilave edilmiştir. Karışımlar çalkalamalı su banyosunda (WSB-30, WiseBath, Kore) $37^{\circ} \mathrm{C}$ sicaklikta 100 rpm çalkalama hızıyla karıştırılarak 16 saat süreyle bekletilmiş ve bu işlem ile enzime dirençli olmayan nişastanın hidrolize olup kendisini oluşturan glukoza dönüşmesi sağlanmıştır. Süre sonunda karışım üzerine $4 \mathrm{~mL}$ etil alkol $(\% 99 \mathrm{v} / \mathrm{v})$ ilave edilerek enzimatik reaksiyon durdurulmuş ve örnekler 4500xg hızla 5 dakika santrüfüj edilmiştir. Çökeltideki glukozun tamamen uzaklaştırılabilmesi için pelletler $8 \mathrm{~mL}$ etil alkol-su çözeltisi (\%50 v/v) ile 2 kez yrkanmış ve 4500xg hızla 5 dakika daha santrifüjlenerek sıvı kısımlar 
yeniden ayrilmıştır. Elde edilen pelletler $40^{\circ} \mathrm{C}$ sıcaklığındaki vakumlu etüvde (VO200, Memmert, Almanya) 30 dakika bekletilerek kurutulmuş ve daha sonra üzerlerine örnekte bulunan EDN'nin çözünmesi için; $2 \mathrm{~mL}, 2 \mathrm{M}$ $\mathrm{KOH}$ çözeltisi ilave edilmiştir. Elde edilen karışım buz banyosu içerisine alınmış ve manyetik karıştırıcı ile karıştırılarak 20 dakika bekletilmiştir. $\mathrm{Bu}$ süre sonunda örneklerin üzerine $8 \mathrm{~mL}, 1.2 \mathrm{M}$ sodyum asetat tampon çözeltisi ( $\mathrm{pH}: 3.8)$ ve 0.1 $\mathrm{mL}$ amiloglukozidaz enzimi ilave edilmiş ve örnekler $50^{\circ} \mathrm{C}$ su banyosunda 30 dakika süreyle 5 dakikada bir karıştırılarak bekletilmiştir. Böylelikle çözünmüş olan EDN glukoza kadar hidroliz edilmiştir. Hidroliz edilen örnekler $4500 x g^{2}$ de 5 dakika santrifüj edilmiş ve oluşan berrak sıv1 kısmından $0.1 \mathrm{~mL}$ alınıp üzerine $3 \mathrm{~mL}$ glukoz oksidaz-peroksidaz ayırac1 (GOPOD) ilave edilerek $50^{\circ} \mathrm{C}$ sicaklikta 20 dakika su banyosunda bekletilmiştir. Hidroliz sonunda oluşan glukoz miktar1, spektrofotometre kullanilarak (UV-1800, Shimadzu, Japonya) 510 nm'de kör örneğe (0.1 $\mathrm{mL}, 100 \mathrm{mM}$ sodyum asetat tampon çözeltisi (pH:4.5) + 3 mL GOPOD) karş1 ölçüm yapilmasıyla belirlenmiştir. EDN içeriği aşağıda verilen denklem (1) yardımıyla hesaplanmış ve sonuçlar $\mathrm{g} / 100 \mathrm{~g}$ örnek olarak verilmiştir.

$$
E D N \text { içeri } \breve{g} i=\Delta E * \frac{F}{W} * 9.27
$$

Denklemde belirtilen $\Delta \mathrm{E}, \mathrm{F}$ ve W sırasıyla örneğin absorbansin1, absorbanstan mikrogram dönüşümünü (100/D-glukoz standart absorbans1) ve kurumadde bazında örnek ağıllığını ifade etmektedir (AACC, 2011).

\section{Glisemik indeks analizi}

Kek örneklerinin glisemik indeks değeri, nişasta hidroliz hızının ölçülmesi ile in vitro olarak belirlenmiş̧ir (Goñi vd., 1997). Bu amaçla; 50 mg örnek üzerine $10 \mathrm{~mL} \mathrm{HCl-KCl}$ tampon çözeltisi ( $\mathrm{pH}: 1.5)$ ilave edilmiş ve karışım homojenize edilmiştir. Homojenizat üzerine pepsin (200 $\mathrm{U} / \mathrm{mL}$ ) içeren $\mathrm{HCl}-\mathrm{KCl}$ tampon çözeltisinden 0.2 $\mathrm{mL}$ eklenmiştir. Örnekler $40^{\circ} \mathrm{C}$ sıcaklı̆̆ındaki etüv içerisinde bulunan bir yatay çalkalama cihazına (Rocker 2D Basic, IKA, Staufen, Almanya) yerleştirilmiş ve $50 \mathrm{rpm}$ hızla karıştırılarak 1 saat inkübasyona bırakılmıştır. İnkübasyon sonunda örnek hacimleri tris-maleat tampon çözeltisi (pH:6.9) kullanılarak $25 \mathrm{~mL}$ ve $\mathrm{pH}$ değerleri ise 1 M NaOH kullanılarak 6.9 olacak şekilde ayarlanmıstır. Daha sonra örneklerin üzerine $\alpha$ amilaz $(2.6 \mathrm{U} / \mathrm{mL})$ içeren tris-maleat tampon çözeltisinden (pH:6.9) $5 \mathrm{~mL}$ eklenmiş ve örnekler $37^{\circ} \mathrm{C}$ sıcaklıkta $50 \mathrm{rpm}$ yatay çalkalama hızında 180 dakika boyunca enzimatik hidrolize tabi tutulmuştur.

Enzimatik hidrolizin 30, 60, 90, 120 ve 180. dakikalarında boş tüpler içerisine $1 \mathrm{~mL}$ örnek aktarılmıştır. Aktarılan örneklerin $100^{\circ} \mathrm{C}$ sıcaklıkta 5 dakika bekletilip, 1 dakika girdap karıştırıcı ile karıştırılmasıyla enzim inaktivasyonu sağlanmıştır. Enzim inaktivasyonu sonrasinda örnekler 180 dakikalık süre sonuna kadar $+4^{\circ} \mathrm{C}$ sicaklikta saklanmıştır. Süre sonunda örneklere $3 \mathrm{~mL} 0.4 \mathrm{M}$ sodyum asetat tampon çözeltisi (pH:4.5) ve $60 \mu \mathrm{L}$ amiloglukozidaz enzimi $(3300 \mathrm{U} / \mathrm{mL})$ ilave edilmiştir. $60^{\circ} \mathrm{C}$ sicaklıkta 45 dakika boyunca 5 dakikada bir karıştırılarak inkübe edilen örneklerden cam tüplere $0.1 \mathrm{~mL}$ aktarılmıs ve üzerlerine $3 \mathrm{~mL}$ GOPOD ayıracı ilave edilmiştir. Örnekler $45^{\circ} \mathrm{C}$ sicaklıkta 20 dakika daha inkübe edilmiş ve örneklerin glukoz içerikleri $510 \mathrm{~nm}$ 'de spektrofotometre ile okuma yapılarak aşağıda verilen denklem (2) yardımıyla belirlenmiştir (Simsek, 2011).

$$
\text { Glukoz }(\%)=\frac{\Delta E * \mathrm{~V} * \mathrm{C} * \mathrm{D}}{\Delta \mathrm{S} * \mathrm{~W}} * 100
$$

Formülde belirtilen $\Delta \mathrm{E}, \mathrm{V}, \mathrm{C}, \Delta \mathrm{S}, \mathrm{D}$ ve $\mathrm{W}$ sirasiyla örneğin absorbansını, test çözeltisinin toplam hacmini, kullanilan standardın konsantrasyonunu ve absorbansını, seyreltme faktörünü ve örnek miktarını ifade etmektedir.

Hesaplanan glukoz miktarı, monosakkaritlerin polisakkaritlere dönüşümünü sağlayan 0.9 katsayısı ile çarpılmış ve örneklerde hidroliz olan nişasta içeriği tespit edilmiştir. Hidroliz olan nişasta içeriğinin süreye karşı grafik edilmesiyle oluşturulan nişasta-hidroliz eğrileri Goñi vd. (1997) tarafindan non-lineer olarak modellenmiş olup, bu eğriler aşağıda verilen denkleme göre (3) SigmaPlot Systat 12 (Erkrath, Almanya) programı kullanılarak değerlendirilmiştir. 


$$
C=C_{\infty} *\left(1-e^{-k t}\right)
$$

Formülde belirtilen $\mathrm{C}, \mathrm{C}_{\infty}, \mathrm{k}$ ve $\mathrm{t}$ sirasiyla $\mathrm{t}$ anındaki konsantrasyonu, denge anındaki konsantrasyonu, kinetik sabiti ve seçilen süreyi ifade etmektedir.

Nişasta hidroliz eğrisi altında kalan alanın referans örneğin hidroliz eğrisi altında kalan alana oranı hidroliz indeksi (HI) olarak tanımlanmaktadır. Eğri altında kalan alan (EAA) ise aşağıda verilen denklem (4) yardımıyla hesaplanmıştır.

$$
E A A=C_{\infty}\left(t_{f}-t_{0}\right)-\frac{C_{\infty}}{k}\left(1-e^{-k\left(t_{f}-t_{0}\right)}\right)
$$

Formülde belirtilen $\mathrm{C}_{\infty}, \mathrm{t}_{\mathrm{f}}, \mathrm{t}_{0}$ ve $\mathrm{k}$ sirasiyla denge anındaki konsantrasyonu ( $\left.\mathrm{t}_{180}\right)$, analizin bitiş süresini (180. dakika), analizin başlangıç zamanını (0. dakika) ve kinetik sabitini ifade etmektedir.

Elde edilen nişasta hidroliz indeks değerleri ise aşağıda verilen denklemde (5) kullanılarak örneklerin tahmini glisemik indeks (tGI) değerleri beyaz ekmek üzerinden hesaplanmıştır. Beyaz ekmek referans alınarak hesaplanan tGI değeri ise 1.43 değerine bölünerek glukoz referansina dönüştürülmüş (Schakel vd., 2008) ve sonuçlar glukoz referansına göre verilmiştir.

$$
t G I=39.71+0.549(H I)
$$

\section{Antioksidan aktivite analizi}

Kek örneklerinin antioksidan aktiviteleri Fernández-León vd. (2013) tarafindan bildirilen DPPH (diphenylpicrylhydrazyl) yöntemine göre yöntemde bazı modifikasyonlar yapılarak belirlenmiştir. Bu amaçla; $1 \mathrm{~g}$ örnek tartılmış ve üzerine $9 \mathrm{~mL} \% 80$ metanol çözeltisi eklenerek 2 saat süreyle $40^{\circ} \mathrm{C}$ sıcaklığındaki çalkalamalı su banyosunda $150 \mathrm{rpm}$ hızla karıştırılarak ekstraksiyon işlemi gerçekleştirilmiştir. Ekstraksiyon sonunda örnekler $5^{\circ} \mathrm{C}$ sicaklikta $9000 \mathrm{rpm}$ hızla 5 dakika santrifüj (Sigma 3K18, Almanya) edilmiş ve üstte toplanan berrak kısım ayrılmıştır. Ayrılan berrak kısımdan alınan 0.95 $\mathrm{mL}$ ekstrakt üzerine $50 \mu \mathrm{L}$ DPPH çözeltisi eklenmiştir. Elde edilen karışım karanlık ortamda 30 dakika bekletilmiş ve süre sonunda örneklerin absorbans değerleri $515 \mathrm{~nm}$ dalga boyunda spektrofotometre ile belirlenmiştir. Örneklerin antioksidan aktivite değerleri troloks kurvesi kullanılarak mg TE/kg olarak hesaplanmıştır (Fernández-León vd., 2013).

\section{Duyusal analiz}

Kek örneklerinin duyusal özellikleri; renk, görünüm, tekstür, gözenek yapıs1, koku, tat ve genel beğeni parametrelerinin 5 puanlık hedonik skala (1: çok kötü, 5: çok iyi) kullanılarak 10 kişilik eğitimli panelist grubu tarafindan puanlanmasıyla ile belirlenmiştir.

\section{İstatistiksel analiz}

Araştırmada kek örneklerinin üretimleri iki tekerrürlü, örneklere yapılan analizler ise paralelli olarak gerçekleştirilmiştir. Elde edilen verilere varyans analizi ve Duncan Çoklu Karşılaştırma Testi uygulanmıştır. Tüm istatistik hesaplamalar SAS istatistik program (Cary, NC, ABD) kullanılarak yapılmıs ve sonuçlar ortalama \pm standart hata şeklinde düzenlenmiştir.

\section{BULGULAR VE TARTIŞMA}

\section{Kek örneklerinin fiziksel özellikleri}

Kek örneklerinin iç ve diş yüzeylerine ait $L^{*}, a^{*}$ ve $b^{*}$ renk değerleri sonuçları Çizelge 1'de verilmiştir. Farklı kek formülasyonlarının, örneklerin iç ve dış yüzeylerindeki renk özellikleri üzerine önemli $(P$ $<0.01$ ) bir etkisinin bulunduğu belirlenmiştir. Kek örneklerinin iç yüzeylerine ait en yüksek ve en düşük $L^{*}$ renk değerlerinin sırasıyla normal un ve ticari glutensiz un karışımı içeren örneklere ait olduğu tespit edilmiştir. Öğütülmüş çiya veya karabuğday tohumu içeren kek örneklerinin dış yüzeylerine ait $L^{*}$ renk değerlerinin ise diğer kek örneklerine göre daha yüksek olduğu belirlenmiştir. Kek örneklerinin iç ve diş yüzeylerindeki renk farkl1lıklarının bileşimlerinde bulunan tohumlarnn renk özelliklerinden, üretim formülasyonlarındaki farklılıklardan ve bu farklılikların enzimatik olmayan esmerleşme reaksiyonlar1 üzerine olan etkilerinden kaynaklandığ1 değerlendirilmiştir. Kek yüzeylerindeki renk koyulaşmasının isıl işlem etkisi ile meydana gelen Maillard reaksiyonu ve şekerlerin karamelizasyonu nedenleriyle gerçekleştiği bildirilmiştir (Shevkani ve Singh, 
2014). Maillard reaksiyonunun gerçekleşme düzeyi ve hızı örnekte bulunan şeker ve aminoasit bileşim ve miktarına bağlı olarak değişmekte ve böylece örnek yüzeylerinde renk farklilıkları oluşabilmektedir (Fennema vd., 2007).

\begin{tabular}{|c|c|c|c|}
\hline \multicolumn{4}{|c|}{$\begin{array}{c}\text { Cizelge 1. Kek örneklerinin renk özellikleri } \\
\text { Table 1. Color properties of cake samples }\end{array}$} \\
\hline & \multicolumn{3}{|c|}{ İç/Crumb } \\
\hline Örnek/Sample & $L^{*}$ & $a^{*}$ & $b^{*}$ \\
\hline Normal un/Normal flour & $73.38^{a} \pm 0.25$ & $-5.17 c \pm 0.00$ & $33.82^{\mathrm{b}} \pm 0.09$ \\
\hline $\begin{array}{l}\text { Ticari glutensiz un/ Commercial } \\
\text { gluten free flour }\end{array}$ & $59.28^{e} \pm 0.29$ & $-3.24 a \pm 0.08$ & $33.89^{\mathrm{b}} \pm 0.00$ \\
\hline Çiya/Chia & $61.77 \mathrm{~d} \pm 0.38$ & $-3.78^{b} \pm 0.15$ & $27.39 \mathrm{~d} \pm 0.22$ \\
\hline Amarant/Amaranth & $70.51^{\mathrm{cb}} \pm 0.47$ & $-5.32^{c} \pm 0.23$ & $34.82^{b} \pm 0.95$ \\
\hline Kinoa/Quinoa & $71.59^{\mathrm{b}} \pm 0.37$ & $-6.39 \mathrm{~d} \pm 0.02$ & $39.76^{a} \pm 0.06$ \\
\hline Karabuğday/Buckwheat & $69.39 c \pm 0.53$ & $-4.26^{\mathrm{b}} \pm 0.23$ & $30.58^{c} \pm 0.57$ \\
\hline \multirow[t]{2}{*}{ Önem/Sign. } & $* *$ & $* *$ & ** \\
\hline & \multicolumn{3}{|c|}{ Dış/Crust } \\
\hline Normal un/Normal flour & $59.51^{\mathrm{c}} \pm 1.54$ & $10.70^{a} \pm 0.15$ & $38.67^{c} \pm 0.12$ \\
\hline $\begin{array}{l}\text { Ticari glutensiz un/ } \\
\text { Commercial gluten free flour }\end{array}$ & $59.74^{c} \pm 0.43$ & $8.12^{\mathrm{cb}} \pm 0.20$ & $39.38^{c} \pm 1.15$ \\
\hline Çiya/Chia & $67.77 \mathrm{a} \pm 0.47$ & $2.27 \mathrm{e} \pm 0.09$ & $33.11 \mathrm{~d} \pm 0.68$ \\
\hline Amarant/Amaranth & $64.98^{\mathrm{ba}} \pm 0.12$ & $7.68^{c} \pm 0.29$ & $41.97 a \pm 0.26$ \\
\hline Kinoa/Quinoa & $63.20^{\mathrm{b}} \pm 0.34$ & $8.66^{b} \pm 0.22$ & $41.14^{\mathrm{ba}} \pm 0.01$ \\
\hline Karabuğday/Buckwheat & $67.43^{a} \pm 1.00$ & $5.19 \mathrm{~d} \pm 0.23$ & $34.66^{\mathrm{d}} \pm 0.00$ \\
\hline Önem/Sign. & $* *$ & ** & $* *$ \\
\hline
\end{tabular}

Ortalama \pm standart hata / Mean \pm standard error

Kek örneklerinin fiziksel özelliklerine ait sonuçlar Çizelge 2'de verilmiştir. Farklı kek formülasyonlarının örneklerin spesifik hacim özellikleri üzerine önemli $(P>0.05)$ bir etkisinin bulunmadığı; ancak sertlik, esneklik, yapışkanlık, çiğnenebilirlik ve sakızımsılık gibi tekstürel özellikleri üzerine önemli $(P<0.01 ; P<0.05)$ bir etkisinin bulunduğu belirlenmiştir.

Kek örneklerinin ortalama spesifik hacim değerinin $3.41 \mathrm{~mL} / \mathrm{g}$ olduğu tespit edilmiştir. Spesifik hacim değerleri arasında örnekler arasında istatistiksel açıdan bir fark bulunmamasına rağmen, normal un $(3.73 \mathrm{~mL} / \mathrm{g})$ ve ögütülmüş çiya tohumu içeren $(3.65 \mathrm{~mL} / \mathrm{g})$ örneklerin spesifik hacim değerlerinin, diğer örneklere göre deskriptif olarak daha yüksek olduğu belirlenmiştir. Buğday ununda bulunan glutenin gaz tutma özelliği ve çiya tohumunun ise içerdiği gam nedeniyle su bulunan ortamlarda jelleşerek oluşturduğu kıvamlı yapı sayesinde kek örneklerinin hacmini arttırdığı değerlendirilmiştir.
Ögütülmüş kinoa tohumu içeren kek örneklerinin sertlik, çiğnenebilirlik ve sakızımsılık değerlerinin diğer kek örneklerine göre daha yüksek olduğu, öğütülmüş çiya ve amarant tohumu içeren kek örneklerinin ise daha yumuşak bir yapıya sahip olduğu ve daha kolay çiğnenebilirlik özelliği gösterdiği belirlenmiştir.

\section{Kek örneklerinin kimyasal özellikleri}

Kek örneklerinin kimyasal özelliklerine ait sonuçlar Çizelge 3'te verilmiştir. Farklı kek formülasyonlarının örneklerin nem içeriği, su aktivitesi, dirençli nişasta, glisemik indeks ve antioksidan aktivite değerleri üzerine önemli ( $P$ $<0.01 ; \quad P<0.05)$ bir etkisinin bulunduğu belirlenmiştir.

Kek örneklerinin nem içeriği değerlerinin \%11.3613.08 arasında değiştiği ve en yüksek nem içeriği değerinin öğütülmüş amarant tohumu içeren kek örneklerine, en düşük nem içeriği değerinin ise normal ticari un içeren kek örneklerine ait olduğu 
belirlenmiştir. Kek örneklerinin su aktivitesi değerlerinin 0.72-0.77 arasında değiştiği ve en yüksek su aktivitesi değerinin ögütülmüss amarant tohumu içeren kek örneklerine, en düşük su aktivitesi değerinin ise ticari glutensiz un karışımı içeren kek örneklerine ait olduğu tespit edilmiştir. Yapılan çeşitli çalışmalarda glutensiz kek örneklerinin nem içeriklerinin 24.50-30.51 g/100 g (Gularte vd., 2012; Levent ve Bilgiçli, 2011) ve su aktivitesi değerlerinin ise 0.82-0.94 (Shevkani ve Singh, 2014; Rothschild vd., 2015) arasinda değiştiği rapor edilmiştir. Araştırmada elde edilen sonuçların literatürde bildirilen değerlerden düşük olduğu ve bu durumun formülasyonlardaki ve pişirme koşullarındaki (sıcaklık, süre, ürün miktarı vb.) farklıliklardan kaynaklandığ1 değerlendirilmiştir.

Cizelge 2. Kek örneklerinin fiziksel özellikleri

Table 2. Physical properties of cake samples

\begin{tabular}{lccc}
\hline Örnek/ Sample & $\begin{array}{c}\text { Spesifik hacim/ } \\
\text { Specific volume } \\
(\mathrm{mL} / \mathrm{g})\end{array}$ & $\begin{array}{c}\text { Sertlik/Hardness } \\
(\mathrm{g})\end{array}$ & $\begin{array}{c}\text { Esneklik/ } \\
\text { Springiness }\end{array}$ \\
\hline Normal un/Normal flour & $3.73 \pm 0.36$ & $1608.22^{\mathrm{ba}} \pm 12.85$ & $0.81^{\mathrm{b}} \pm 0.01$ \\
Ticari glutensiz un/ & $3.34 \pm 0.19$ & $1486.80^{\mathrm{b}} \pm 43.00$ & $0.83^{\mathrm{b}} \pm 0.01$ \\
Commercial gluten free flour & $3.65 \pm 0.09$ & $1234.21^{\mathrm{c}} \pm 42.79$ & $0.82^{\mathrm{b}} \pm 0.00$ \\
Çiya/Chia & $3.09 \pm 0.23$ & $1338.31^{\mathrm{c}} \pm 49.00$ & $0.85^{\mathrm{a}} \pm 0.01$ \\
Amarant/Amaranth & $3.29 \pm 0.01$ & $1709.50^{\mathrm{a}} \pm 33.20$ & $0.83^{\mathrm{b}} \pm 0.01$ \\
Kinoa/Quinoa & $3.36 \pm 0.15$ & $1559.47^{\mathrm{a}} \pm 40.74$ & $0.81^{\mathrm{b}} \pm 0.00$ \\
Karabuğday/Buckwheat & - & $* *$ & $*$ \\
Önem/Sign. & Yapişkanlik/ & Çiğnenebilirlik/ & Sak1zimsillk/ \\
\hline Örnek/ Sample & Adhesiveness & Chewiness & Gumminess \\
\hline Normal un/Normal flour & $0.65^{\mathrm{c}} \pm 0.01$ & $842.06^{\mathrm{b}} \pm 3.30$ & $1041.88^{\mathrm{b}} \pm 17.05$ \\
Ticari glutensiz un/ & $0.66^{\mathrm{bc}} \pm 0.01$ & $808.38^{\mathrm{cb}} \pm 32.09$ & $979.89^{\mathrm{b}} \pm 35.51$ \\
Commercial gluten free flour & $0.677^{\mathrm{bc}} \pm 0.01$ & $668.09^{\mathrm{c}} \pm 21.41$ & $819.40^{\mathrm{c}} \pm 22.82$ \\
Çiya/Chia & $0.72^{\mathrm{a}} \pm 0.01$ & $807.93^{\mathrm{cb}} \pm 32.38$ & $954.86^{\mathrm{c}} \pm 33.05$ \\
Amarant/Amaranth & $0.70^{\mathrm{b}} \pm 0.03$ & $996.27^{\mathrm{a}} \pm 91.79$ & $1199.18^{\mathrm{a}} \pm 80.34$ \\
Kinoa/Quinoa & $0.63^{\mathrm{c}} \pm 0.00$ & $797.71^{\mathrm{cb}} \pm 14.32$ & $984.14^{\mathrm{b}} \pm 22.19$ \\
Karabuğday/Buckwheat & $*$ & $*$ & $* *$ \\
Önem/Sign. & & &
\end{tabular}

Ortalama \pm standart hata / Mean \pm standard error

Cizelge 3. Kek örneklerinin kimyasal özellikleri

Table 3. Chemical properties of cake samples

\begin{tabular}{lccccc}
\hline Örnek/ Sample & $\begin{array}{c}\text { Nem/ Moisture } \\
(\%)\end{array}$ & $\begin{array}{c}\text { Su aktivitesi/ } \\
\text { Water activity }\end{array}$ & $\begin{array}{c}\text { Dirençli nişasta/ } \\
\text { Resistant starch } \\
(\%)\end{array}$ & $\begin{array}{c}\text { Glisemik indeks/ } \\
\text { Glycemic index }\end{array}$ & $\begin{array}{c}\text { Antioksidan } \\
\text { aktivite/ } \\
\text { Antioxidant activity } \\
(\mathrm{mg} \text { TE/kg) }\end{array}$ \\
\hline $\begin{array}{l}\text { Normal un/Normal flour } \\
\text { Ticari glutensiz un/ }\end{array}$ & $11.36^{\mathrm{b}} \pm 0.31$ & $0.73^{\mathrm{d}} \pm 0.00$ & $0.28^{\mathrm{b}} \pm 0.01$ & $44.20^{\mathrm{ba}} \pm 0.44$ & $176.11^{\mathrm{c}} \pm 5.02$ \\
Commercial gluten-free & $12.06^{\mathrm{ba}} \pm 0.47$ & $0.72^{\mathrm{e}} \pm 0.00$ & $0.36^{\mathrm{a}} \pm 0.02$ & $42.71^{\mathrm{b}} \pm 0.47$ & $395.48^{\mathrm{a}} \pm 0.85$ \\
flour & & & & & \\
Çiya/Chia & $12.17^{\mathrm{ba}} \pm 0.11$ & $0.75^{\mathrm{c}} \pm 0.01$ & $0.17 \mathrm{c} \pm 0.02$ & $44.27^{\mathrm{ba}} \pm 0.52$ & $225.177^{\mathrm{b}} \pm 8.57$ \\
Amarant/Amaranth & $13.08^{\mathrm{a}} \pm 0.67$ & $0.77^{\mathrm{a}} \pm 0.00$ & $0.21^{\mathrm{cb}} \pm 0.04$ & $45.93^{\mathrm{a}} \pm 0.32$ & $74.76^{\mathrm{d}} \pm 2.62$ \\
Kinoa/Quinoa & $11.39^{\mathrm{b}} \pm 0.02$ & $0.76^{\mathrm{b}} \pm 0.00$ & $0.22^{\mathrm{cb}} \pm 0.02$ & $45.60^{\mathrm{a}} \pm 1.33$ & $82.76^{\mathrm{d}} \pm 7.54$ \\
$\begin{array}{l}\text { Karabuğday/Buckwheat } \\
\text { Önem/Sign. }\end{array}$ & $11.62^{\mathrm{b}} \pm 0.00$ & $0.75^{\mathrm{c}} \pm 0.00$ & $0.19^{\mathrm{c}} \pm 0.03$ & $45.42^{\mathrm{ba}} \pm 1.30$ & $172.86^{\mathrm{c}} \pm 6.92$ \\
\hline
\end{tabular}

Ortalama \pm standart hata / Mean \pm standard error 
Kek örneklerinin dirençli nişasta değerlerinin \%0.17-0.36 arasında değiştiği ve en yüksek dirençli nişasta değerinin ticari glutensiz un karışımı içeren kek örneklerine, en düşük dirençli nişasta değerinin ise ögütülmüş çiya tohumu içeren kek örneklerine ait olduğu tespit edilmiştir. Dirençli nişasta, tüketildikten sonra ince bağırsakta 120 dakika içerisinde D-glukoza hidrolize edilemeyen ve ancak kolon mikrofloras tarafindan fermente edilebilen nişasta fraksiyonu olarak tanımlanmaktadır (Fuentes-Zaragoza vd., 2010). Genellikle gluten içeren eşdeğerlerine göre glutensiz ürünlerin dirençli nişasta içerikleri düşük, glisemik indeks değerleri ise yüksektir. Bu ürünlerdeki yüksek nişasta sindirilebilirliği; nişastanın tipi ve kaynağı, besinsel lif miktarı ve çeşidi, protein ve lipit matriksinin varllğı ve işleme yöntemi sonucunda gidada oluşan makroskobik yapıya bağlı olarak değişmektedir (Giuberti ve Gallo, 2018). Yapılan bir çalışmada karabuğday ve amarant unları, kullanılan unun yaklaşı \%30'u oranında bisküvi hamuruna eklenmiş ve elde edilen bisküvilerin dirençli nişasta içerikleri yaklaşık \%6 olarak belirlenmiştir (Vujić vd., 2014). Mevcut çalışmada tahıl benzeri ürün unlarının oldukça düşük miktarda formülasyona eklenmesi ve nihai ürünün dirençli nişasta içeriğinin belirlenmesinde sorunlara neden olan protein ve lipitler bakımından zengin bir ürün olması nedenleriyle kek örneklerinin dirençli nişasta içeriklerinin düşük olarak tespit edildiği değerlendirilmiştir.

Kek örneklerinin glisemik indeks değerlerinin 42.71-45.93 arasında değiştiği ve en yüksek glisemik indeks değerinin ögütülmüss amarant tohumu içeren kek örneklerine, en düşük glisemik indeks değerinin ise ticari glutensiz un karışımı içeren kek örneklerine ait olduğu tespit edilmiştir. Glukoz referans alındığında tGI değeri $\geq 70$ olan gidalar yüksek, $56 \leq \mathrm{tGI} \leq 69$ arasinda olan gidalar orta ve $\mathrm{tGI} \leq 55$ olan gıdalar ise düşük glisemik indeksli gidalar olarak sinıflandirılmaktadır (Schakel vd., 2008). Bu sinıflandırmaya göre, çalışma kapsamında üretilen keklerin düşük glisemik indeksli gıda sınıfinda yer aldığ1 tespit edilmiştir. Yapılan bir çalışmada üretilen glutensiz kek örneklerinin glisemik indeks değerinin ortalama 42.20 olduğu bildirilmiştir (Scazzina vd., 2015).

Kek örneklerinin antioksidan aktivite değerlerinin 74.76-395.48 mg TE/kg değerleri arasında değiştiği ve en yüksek antioksidan aktivite değerinin ticari glutensiz un karışımı içeren kek örneklerine, en düşük antioksidan aktivite değerinin ise ögütülmüş amarant ve kinoa tohumu içeren kek örneklerine ait olduğu tespit edilmiştir. Normal un ve ticari glutensiz un karışımları ile üretilen keklerin antioksidan aktivitesinin yüksek olmasının bu unların üretimi sırasında ilave edilen askorbik asit gibi antioksidan etkili katkılardan kaynaklanmış olabileceği değerlendirilmiştir. Yapılan bir çalışmada amarant ve kinoa unu içeren ekmek örneklerinin antioksidan aktivitelerinin karabuğday içeren ekmeklere göre daha düşük olduğu bildirilmiştir (Chlopicka vd., 2012). Bir diğer çalışmada ise karabuğday ve kinoa tanelerinin amarant tanelerine göre sirasiyla yaklaşık 22 ve 2 kat daha yüksek bir antioksidan aktiviteye sahip oldukları bildirilmiştir (AlvarezJubete vd., 2010).

\section{Kek örneklerinin duyusal özellikleri}

Kek örneklerinin duyusal özelliklerine ait sonuçlar Çizelge 4'te verilmiştir. Farklı kek formülasyonlarının örneklerin renk, görünüm, tekstür, gözenek yapısı, koku, tat ve genel beğeni duyusal özellikleri üzerine önemli $(P<0.01 ; P$ $<0.05)$ bir etkisinin bulunduğu belirlenmiştir. Gluten içermeyen formülasyonlar kendi aralarında kıyaslandığında ise tahıl benzeri ürün tohumları ile hazırlanan kek örneklerinin, ticari glutensiz un karışımı ile hazırlanan kek örneklerine göre panelistler tarafindan daha çok beğenildiği ve bu örneklerin 5 puanlık hedonik skala üzerinden 3.50 ve üzerinde puanlar almaları nedeniyle duyusal açıdan kabul edilebilir olduğu değerlendirilmiştir. Tahıl benzeri ürünler içeren kek örnekleri arasından ise; tekstür, koku, tat ve genel beğeni parametreleri bakımından öğütülmüss çiya tohumu içeren örneklerin daha yüksek puanlar aldığı tespit edilmiştir. 
Cizelge 4. Kek örneklerinin duyusal özellikleri

Table 4. Sensorial properties of cake samples

\begin{tabular}{|c|c|c|c|c|}
\hline Örnek/ Sample & Renk/Color & \multicolumn{2}{|c|}{ Görünüm/Appearance } & Tekstür/Texture \\
\hline Normal un/Normal flour & $4.35 \mathrm{a} \pm 0.05$ & \multicolumn{2}{|c|}{$4.35^{a} \pm 0.15$} & $3.80^{\mathrm{ba}} \pm 0.30$ \\
\hline $\begin{array}{l}\text { Ticari glutensiz un/ } \\
\text { Commercial gluten free flour }\end{array}$ & $3.35^{c} \pm 0.05$ & \multicolumn{2}{|c|}{$3.35^{c} \pm 0.05$} & $3.25^{\mathrm{ba}} \pm 0.25$ \\
\hline Çiya/Chia & $2.80^{\mathrm{d}} \pm 0.10$ & \multicolumn{2}{|c|}{$2.80^{\mathrm{d}} \pm 0.10$} & $4.05^{a} \pm 0.15$ \\
\hline Amarant/Amaranth & $3.80^{\mathrm{b}} \pm 0.10$ & \multicolumn{2}{|c|}{$3.80^{\mathrm{cb}} \pm 0.20$} & $3.35^{\mathrm{ba}} \pm 0.35$ \\
\hline Kinoa/Quinoa & $3.85^{b} \pm 0.15$ & \multicolumn{2}{|c|}{$3.85^{b} \pm 0.15$} & $3.20^{\mathrm{b}} \pm 0.10$ \\
\hline Karabuğday/Buckwheat & $3.75^{b} \pm 0.05$ & \multicolumn{2}{|c|}{$3.75^{\mathrm{cb}} \pm 0.05$} & $3.30^{\mathrm{ba}} \pm 0.10$ \\
\hline Önem/Sign. & ** & \multicolumn{2}{|c|}{ ** } & $*$ \\
\hline Örnek/ Sample & $\begin{array}{l}\text { Gözenek yap1s1/ } \\
\text { Pore structure }\end{array}$ & Koku/Odor & Tat/Taste & $\begin{array}{c}\text { Genel beğeni/ } \\
\text { Overall }\end{array}$ \\
\hline Normal un/Normal flour & $3.90^{a} \pm 0.20$ & $4.40^{a} \pm 0.00$ & $4.30^{a} \pm 0.20$ & $4.35^{a} \pm 0.15$ \\
\hline $\begin{array}{l}\text { Ticari glutensiz un/ } \\
\text { Commercial gluten free flour }\end{array}$ & $3.35^{b} \pm 0.05$ & $2.65^{c} \pm 0.25$ & $2.35^{d} \pm 0.35$ & $2.90^{c} \pm 0.40$ \\
\hline Çiya/Chia & $3.60^{\mathrm{ba}} \pm 0.10$ & $4.00^{\mathrm{ba}} \pm 0.10$ & $4.25^{\mathrm{ba}} \pm 0.15$ & $4.00^{\mathrm{ba}} \pm 0.10$ \\
\hline Amarant/Amaranth & $3.55^{\mathrm{ba}} \pm 0.05$ & $3.85^{\mathrm{ba}} \pm 0.05$ & $3.50^{\mathrm{bc}} \pm 0.00$ & $3.50^{\mathrm{bc}} \pm 0.00$ \\
\hline Kinoa/Quinoa & $3.75^{a} \pm 0.05$ & $3.40^{\mathrm{b}} \pm 0.40$ & $3.60^{\mathrm{bac}} \pm 0.30$ & $3.60^{\mathrm{bc}} \pm 0.20$ \\
\hline Karabuğday/Buckwheat & $3.80^{\mathrm{a}} \pm 0.10$ & $3.35^{b c} \pm 0.15$ & $3.35^{c} \pm 0.05$ & $3.60^{b c} \pm 0.00$ \\
\hline Önem/Sign. & $*$ & $*$ & ** & * \\
\hline
\end{tabular}

Ortalama \pm standart hata / Mean \pm standard error

\section{SONUÇ}

Kek örneklerinin spesifik hacimlerinin benzer olduğu, tekstür değerlerinin ise farklllık gösterdiği ve çiya tohumu katkısiyla üretilen keklerin diğer keklerden daha yumuşak nitelikte olduğu tespit edilmiştir. Farklı tahıl benzeri ürün ilavesi ile üretilen kek örneklerinin dirençli nişasta ve glisemik indeks değerleri birbirine yakın bulunurken; çiya tohumu ilavesi ile üretilen kek örneklerinin antioksidan aktivite değerlerinin, amarant ve kinoa ilavesi ile üretilen kek örneklerinin antioksidan aktivitelerinden yaklaşık 3 kat daha yüksek olduğu tespit edilmiştir. Duyusal değerlendirme sonuçlarına göre ise; çiya tohumu ilavesi ile üretilen kek örneklerinin genel beğeni puanının, gluten içermeyen karışımlarla hazırlanan kek örneklerinden daha yüksek ve normal un ile hazırlanan kek örneklerine en yakın duyusal değerlendirmeye sahip olduğu belirlenmiştir. Sonuç olarak; glutensiz keklerin çeşitlendirilmesinde tahıl benzeri ürünlerin kullanılabileceği ve bunların arasında ise çiyanın belirtilen özellikleri itibariyle öne çıktı̆̆1 sonucuna ulaşılmıştır.

\section{KAYNAKLAR}

AACC. (2011). Approved Methods of the American Association of Cereal Chemists (Method 32-40). American Association of Cereal Chemists, St. Paul, MN.

Abadie, V., Sollid, L.M., Barreiro, L.B., Jabri, B. (2011). Integration of genetic and immunological insights into a model of celiac disease pathogenesis. Annu Rev Immunol, 29: 493-525.

Alvarez-Jubete, L., Wijngaard, H., Arendt, E., Gallagher, E. (2010). Polyphenol composition and in vitro antioxidant activity of amaranth, quinoa buckwheat and wheat as affected by sprouting and baking. Food Chem, 119(2): 770-778.

Arendt, E., Dal Bello, F. (2011). Gluten-free cereal products and beverages. Academic Press, Elsevier, San Diego, ABD, 443 s.

Bernardo, D., Peña, A. (2012). Developing strategies to improve the quality of life of patients with gluten intolerance in patients with and without coeliac disease. Eur J Intern Med, 23(1): 68. 
Chlopicka, J., Pasko, P., Gorinstein, S., Jedryas, A., Zagrodzki, P. (2012). Total phenolic and total flavonoid content, antioxidant activity and sensory evaluation of pseudocereal breads. $L W T$ - Food Sci Technol, 46(2): 548-555

Delcour, J.A., Joye, I.J., Pareyt, B., Wilderjans, E., Brijs, K., Lagrain, B. (2012). Wheat gluten functionality as a quality determinant in cerealbased food products. Annu Rev Food Sci Tecbnol, 3: 469-492.

Fennema, O.R., Damodaran, S., Parkin, K.L. (2007). Fennema's food chemistry. CRC Press, $1107 \mathrm{~s}$.

Fernández-León, M., Fernández-León, A., Lozano, M., Ayuso, M., Amodio, M., Colelli, G., González-Gómez, D. (2013). Retention of quality and functional values of broccoli 'Parthenon'stored in modified atmosphere packaging. Food Control, 31(2): 302-313.

Fuentes-Zaragoza, E., Riquelme-Navarrete, M.J., Sánchez-Zapata, E., Pérez-Álvarez, J.A. (2010). Resistant starch as functional ingredient: A review. Food Res Int, 43(4): 931-942.

Giuberti, G., Gallo, A. (2018). Reducing the glycaemic index and increasing the slowly digestible starch content in gluten-free cerealbased foods: a review. Int J Food Sci \& Technol, 53(1): 50-60.

Goñi, I., Garcia-Alonso, A., Saura-Calixto, F. (1997). A starch hydrolysis procedure to estimate glycemic index. Nutr Res, 17(3): 427-437.

Gularte, M.A., de la Hera, E., Gómez, M., Rosell, C.M. (2012). Effect of different fibers on batter and gluten-free layer cake properties. LWT-Food Sci Technol, 48(2): 209-214.

Gutiérrez, T.J. (2018). Plantain flours as potential raw materials for the development of gluten-free functional foods. Carbohyd Polym, 202: 265-279.

Levent, H., Bilgiçli, N. (2011). Enrichment of gluten-free cakes with lupin (Lupinus albus L.) or buckwheat (Fagopyrum esculentum M.) flours. Int J Food Sci Nutr, 62(7): 725-728.
Linares-García, L., Repo-Carrasco-Valencia, R., Paulet, P.G., Schoenlechner, R. (2019). Development of gluten-free and egg-free pasta based on quinoa (Chenopdium quinoa Willd) with addition of lupine flour, vegetable proteins and the oxidizing enzyme POx. Eur Food Res Technol, 1-10.

Pellegrini, N., Agostoni, C. (2015). Nutritional aspects of gluten-free products. J Sci Food Agric, 95(12): 2380-2385.

Román, L., González, A., Espina, T., Gómez, M. (2017). Degree of roasting of carob flour affecting the properties of gluten-free cakes and cookies. $J$ Food Sci Technol, 54(7): 2094-2103.

Rosell, C.M., Barro, F., Sousa, C., Mena, M.C. (2014). Cereals for developing gluten-free products and analytical tools for gluten detection. J Cereal Sci, 59(3): 354-364.

Rothschild, J., Rosentrater, K.A., Onwulata, C., Singh, M., Menutti, L., Jambazian, P., Omary, M.B. (2015). Influence of quinoa roasting on sensory and physicochemical properties of allergen-free, gluten-free cakes. Int J Food Sci \& Technol, 50(8): 1873-1881.

Scazzina, F., Dall'Asta, M., Pellegrini, N., Brighenti, F. (2015). Glycaemic index of some commercial gluten-free foods. Eur J Nutr, 54(6): 1021-1026.

Schakel, S., Schauer, R., Himes, J., Harnack, L., Van Heel, N. (2008). Development of a glycemic index database for dietary assessment. J Food Compos Anal, 21: S50-S55.

Shevkani, K., Singh, N. (2014). Influence of kidney bean, field pea and amaranth protein isolates on the characteristics of starch-based gluten-free muffins. Int J Food Sci \& Technol, 49(10): 2237-2244.

Simsek, S. (2011). Gölevez (Colocasia esculenta L. Schott) yumrusundan dirençli nişasta elde edilmesi ve sağlık üzerine etkilerinin in vitro yöntemlerle saptanması. Ege Üniversitesi G1da Mühendisliği Bölümü Doktora Tezi, İzmir, 89 s. 
Vujić, L., Vitali Čepo, D., Šebečić, B., Dragojević, I.V. (2014). Effects of pseudocereals, legumes and inulin addition on selected nutritional properties and glycemic index of whole grain wheat-based biscuits. J Food Nutr Res, 53(2): 152-161.

Wilderjans, E., Luyts, A., Brijs, K., Delcour, J.A. (2013). Ingredient functionality in batter type cake making. Trends Food Sci Technol, 30(1): 6-15.
Zuidmeer, L., Goldhahn, K., Rona, R.J., Gislason, D., Madsen, C., Summers, C., Sodergren, E., Dahlstrom, J., Lindner, T., Sigurdardottir, S.T. (2008). The prevalence of plant food allergies: a systematic review. J Allergy Clin Immunol, 121(5): 1210-1218.e1214. 